\title{
THE SUBMERSION OF PEDILANTHUS INTO EUPHORBIA (EUPHORBIACEAE)
}

\author{
Victor W. Steinmann \\ Instituto de Ecología, A.C., Centro Regional del Bajío \\ Apartado postal 386, 61600 Pátzcuaro, Michoacán
}

\begin{abstract}
Pedilanthus (Euphorbiaceae) consists of about 15 species, all of which occur in Mexico. The genus belongs to the tribe Euphorbieae subtribe Euphorbiinae in the subfamily Euphorbioideae, and is one of six satellite genera of Euphorbia. As traditionally suspected, molecular studies have demonstrated that Euphorbia is paraphyletic, and the satellite genera are nested within it. In order to create a classification of Euphorbieae subtribe Euphorbiinae that reflects evolutionary relationships and employs the concept of monophyly, I argue that the genera currently segregated from Euphorbia should be included within it. Therefore, Pedilanthus is here treated as a synonym of Euphorbia. A list enumerating the valid names for species of Pedilanthus when treated within Euphorbia is provided. The following new combinations and names are proposed: Euphorbia calcarata, Euphorbia coalcomanensis, Euphorbia colligata, Euphorbia conzattii, Euphorbia cymbifera, Euphorbia cyri, Euphorbia diazlunana, Euphorbia dressleri, Euphorbia finkii, Euphorbia lomelii, Euphorbia peritropoides, Euphorbia personata, Euphorbia tehuacana, and Euphorbia tithymaloides sspp. angustifolia, bahamensis, jamaicensis, padifolia, parasitica, retusa, and smallii.
\end{abstract}

Key words: classification, Euphorbia, Euphorbiaceae, Pedilanthus.

\section{RESUMEN}

Pedilanthus (Euphorbiaceae) contiene alrededor de 15 especies, todas ellas se encuentran en México. El género pertenece a la tribu Euphorbieae subtribu Euphorbiinae de la subfamilia Euphorbioideae y es uno de los seis géneros satélites de Euphorbia. Como tradicionalmente se ha sospechado, los estudios moleculares han demostrado que Euphorbia es un conjunto parafilético y que los otros géneros de la subtribu se concentran dentro de él. Para tener una clasificación de Euphorbieae subtribu Euphorbiinae que refleje mejor su historia evolutiva y que siga el concepto de monofilia, es necesario que los géneros satélites se incluyan en Euphorbia. Por consiguiente, Pedilanthus aquí se trata como un sinónimo de Euphorbia. Se incluye una lista de los nombres válidos para las especies de Pedilanthus cuando se consideran como parte de Euphorbia y se proponen las siguientes combinaciones o nombres nuevos: Euphorbia calcarata, Euphorbia coalcomanensis, Euphorbia colligata, Euphorbia conzattii, Euphorbia cymbifera, Euphorbia cyri, Euphorbia diazlunana, Euphorbia dressleri, Euphorbia finkii, Euphorbia Iomelii, Euphorbia peritropoides, Euphorbia personata, Euphorbia tehuacana y Euphorbia tithymaloides sspp. angustifolia, bahamensis, jamaicensis, padifolia, parasitica, retusa y smallii.

Palabras clave: clasificación, Euphorbia, Euphorbiaceae, Pedilanthus. 
The genus Pedilanthus Neck. ex Poit., nom. cons., consists of about 15 species. All of these occur in Mexico, and most are endemic to the country. A few species extend into Central America, and only one, Pedilanthus tithymaloides (L.) Poit., is widespread, ranging from southern Florida and Mexico to northern South America and the Caribbean (Dressler, 1957). Linnaeus (1753) treated the single then-known species of Pedilanthus within Euphorbia, but subsequently the genus has been almost universally accepted since its inception in the early $19^{\text {th }}$ century. Klotzsch and Garcke $(1859 ; 1860)$ went so far as to divide the genus into three: Diadenaria Klotzsch \& Garcke, Hexadenia Klotzsch \& Garcke, and Pedilanthus. However, their system was never adopted.

Following the familial classification of Webster (1994), Pedilanthus, along with other cyathiate members of Euphorbiaceae, belongs to tribe Euphorbieae in the subfamily Euphorbioideae. The genus is placed in subtribe Euphorbiinae, an assemblage containing seven genera and dominated by the massive genus Euphorbia. Of Euphorbia's six satellite genera, all except Chamaescye are distinguished by features of involucral morphology. Also, all except Chamaescye are universally accepted, whereas Chamaesyce is considered a synonym of Euphorbia by many experts on the subtribe Euphorbiinae (e.g., Johnston, 1975; Carter, 1988).

Pedilanthus is distinguished from Euphorbia by the possession of styles connate into a long column and bilaterally symmetrical cyathia that have the glands hidden within a nectar spur (Webster, 1994). It is worth noting, however, that the former characteristic is not restricted to Pedilanthus and can be found in various Euphorbia, e.g., E. adenochila S. Carter. With the exception of its unusual involucral morphology, Pedilanthus differs in no substantial way from Euphorbia. In fact, it has long been suspected that the genus Pedilanthus arose from ancestral Euphorbia under the selection of hummingbird pollination (Dressler, 1957; Webster, 1967), and both these authors suggested an origin from within Euphorbia subg. Agaloma.

Until recently, little was known about the phylogeny and relationships of Euphorbia and its segregate genera. In a broad phylogenetic analysis of the tribe Euphorbieae based on DNA sequence data (Steinmann and Porter, 2002), it was demonstrated that the subtribe Euphorbiinae is strongly supported to be monophyletic, but Pedilanthus, as well as the other satellite genera, are nested within Euphorbia. Therefore, viewed in a global and evolutionary context, Pedilanthus and the other segregates represent small, scattered branches within a large tree of Euphorbia. As a result, some members of Euphorbia are actually more closely related to members of other genera than to other members of Euphorbia. In the case of Pedilanthus, molecular data from the chloroplast coding region $n d h \mathrm{~F}$ suggest that the neotropical species Euphorbia elata Brandegee is more closely related to species of Pedilanthus than it is to other species of Euphorbia (Steinmann and Porter, 2002). Although the exact affinities of Pedilanthus are still not manifest, the group apparently is not closely related to members of Euphorbia subg. Agaloma, as previously suggested. Instead it appears related to Euphorbia elata in a clade with various other neotropical Euphorbia, such as E. cestrifolia H.B.K., E. 
hoffmanniana (Klotzsch \& Garcke) Boiss., and E. pteroneura A. Berger (Steinmann and Porter, 2002).

If the modern classification of Euphorbieae subtribe Euphorbiinae is to reflect evolutionary relationships and employ the concept of monophyly, then there are two alternative solutions to the current problem of paraphyly within the subtribe. The first is a narrowly delimitated Euphorbia and a multitude of segregate genera. Euphorbia would be restricted to the nearly 250 species currently recognized as Euphorbia subgenus Euphorbia (see discussion in Steinmann and Porter, 2002), and the remainder of the species in the subtribe, around 1800, would require accommodation in other genera. As many as forty genera would probably be needed to accommodate the species currently recognized within the single genus Euphorbia. As a result, Euphorbia, a well-known and easily recognizable genus, would no longer exist in most parts of world. I believe that this would lead to great instability for at least the foreseeable future as boundaries, distinguishing features, and circumscriptions of these genera are elucidated. Furthermore, I believe that many of resulting genera would be nearly impossible to distinguish from each other on the basis of morphology. This is due to the unusual nature of evolution within subtribe Euphorbiinae. In general, basic cyathial morphology is highly conserved but vegetative morphology is highly plastic, thus leading to great diversification and much parallel evolution in growth form with little change in the overall structure of the cyathium. As a result, changes in cyathial structure, as demonstrated by Pedilanthus, have been given great taxonomic weight, and those groups possessing such changes have been deemed worthy of generic distinction. In contrast, equally significant changes in vegetative structure, such as those resulting in leafless, cactiform succulents, have been taxonomically ignored.

The second alternative, and the one that I advocate, is to expand the circumscription of Euphorbia to include the species currently treated in segregate genera. Under this solution, the circumscription of Euphorbia only slightly changes to encompass taxa with unusual cyathial morphologies. Considering the great amount of vegetative diversity currently present within the genus, I do not think that such an expansion drastically alters its generic concept. On the contrary, broadening the genus has some benefit because it conveys the incredible diversification of the group in both vegetative and cyathial features. Thus, for the reasons elaborated here and others presented in Steinmann and Porter (2002), I relegate Pedilanthus to synonymy under Euphorbia.

There is still much doubt concerning subgeneric classification within Euphorbia, and at this time I do not propose whether Pedilanthus should be treated as a subgenus or a section of Euphorbia. Certainly recognition at one of these ranks is appropriate, and future investigations on infrageneric relationships within Euphorbia will help determine its best status.

The following list enumerates the valid names for species of Pedilanthus when treated within Euphorbia. In most cases new combinations are required and in some cases a new name is needed because the use of an epithet in Euphorbia would result in a later homonym. 
Euphorbia bracteata Jacq., PI. Hort. Schoenbr. 3: 14. 1798. (=Pedilanthus bracteatus (Jacq.) Boiss. in DC., Prodr. 15(2): 6. 1862).

Euphorbia calcarata (Schltdl.) V. W. Steinm., comb. nov. (=Pedilanthus calcaratus Schltdl., Linnaea 19: 255. 1847).

Euphorbia coalcomanensis (Croizat) V. W. Steinm., comb. nov. (=Pedilanthus coalcomanensis Croizat, J. Wash. Acad. Sci. 33: 19. 1943).

Euphorbia colligata V. W. Steinm., nom. nov. (=Pedilanthus connatus Dressler \& Sacamano, Acta Bot. Mex. 18: 21. 1992). A new name is required because of the existence of Euphorbia connata Boiss., published in 1862. The new specific epithet, meaning joined, is in reference to the high degree of fusion among the involucral lobes of the nectar spur.

Euphorbia conzattii V. W. Steinm., nom. nov. (=Pedilanthus pulchellus Dressler, Contr. Gray Herb. 182: 111. 1957). A new name is required because of the existence of Euphorbia pulchella Lag. \& Rodr., published in 1802. The specific epithet honors Cassiano Conzatti (1862-1951), botanical explorer and early specialist on the flora of Oaxaca, the state to which this species is endemic; he collected the type in 1917.

Euphorbia cymbifera (Schltdl.) V. W. Steinm., comb. nov. (=Pedilanthus cymbiferus Schltdl., Linnaea 19: 253. 1847).

Euphorbia cyri V. W. Steinm., nom. nov. (=Pedilanthus tomentellus B.L. Rob. \& Greenm., Amer. J. Sci. 50: 164. 1895). A new name is required because of the existence of Euphorbia tomentella Engelm. ex Boiss., published 1862. The new specific epithet honors Cyrus Guernsey Pringle (1838-1911), collector of the type material.

Euphorbia diazlunana (Lomelí \& Sahagún) V. W. Steinm., comb. nov. (=Pedilanthus diazlunanus Lomelí \& Sahagún, Acta Bot. Mex. 25: 15. 1993).

Euphorbia dressleri V. W. Steinm., nom. nov. (=Pedilanthus gracilis Dressler, Contr. Gray Herb. 182: 109. 1957). A new name is required because of the existence of Euphorbia gracilis Loisel., published in 1807. The specific epithet dressleri honors Robert L. Dressler, renowned ochidologist who early in his career worked on Euphorbiaceae and provided the monograph of Pedilanthus.

Euphorbia finkii (Boiss.) V. W. Steinm., comb. nov. (=Pedilanthus finkii Boiss. in DC., Prodr. 15(2): 1261. 1866). 
Euphorbia lomelii V. W. Steinm., nom. nov. (=Pedilanthus macrocarpus Benth., Bot. Voy. Sulphur 49. 1844). A new name is required because of the existence of Euphorbia marcrocarpa Boiss. \& Buhse, published in 1860. It honors José Lomelí Sención, enthusiastic researcher on the Euphorbiaceae and director of the Botanical Garden at the Universidad Autónoma de Guadalajara.

Euphorbia peritropoides (Millsp.) V. W. Steinm., comb. nov. (=Pedilanthus peritropoides Millsp., Publ. Field Mus. Nat. Hist., Bot. ser. 2: 369. 1913; Pedilanthus palmeri Millsp., Publ. Field Mus. Nat. Hist., Bot. ser. 2: 364. 1913). Pedilanthus palmeri and P. peritropoides were published by Millspaugh in the same article, and Dressler (1957) first reduced the latter to synonymy under the former. However, the presence of Euphorbia palmeri Engelm. ex S. Watson, published in 1880, prevents the transfer of $P$. palmeri into Euphorbia.

Euphorbia personata (Croizat) V. W. Steinm., comb. nov. (=Pedilanthus personatus Croizat, J. Wash. Acad. Sci. 33: 20. 1943; Pedilanthus nodiflorus Millsp., Publ. Field Columbian Mus., Bot. ser. 1: 305. 1896). Although the name Pedilanthus nodiflorus has almost 50 years priority over $P$. personatus, the existence of Euphorbia nodiflora Steud., published in 1840, prevents its transfer to Euphorbia.

Euphorbia tehuacana (Brandegee) V. W. Steinm., comb. nov. (=Pedilanthus tehuacanus Brandegee, Univ. Calif. Publ. Bot. 6: 55. 1914).

Euphorbia tithymaloides L., Sp. PI. 453. 1753; ssp. tithymaloides. (=Pedilanthus tithymaloides (L.) Poit., Ann. Mus. Natl. Hist. Nat. 19: 390. 1812; ssp. tithymaloides).

Euphorbia tithymaloides L. ssp. angustifolia (Poit.) V. W. Steinm., comb. nov. (=Pedilanthus angustifolius Poit., Ann. Mus. Natl. Hist. Nat. 19: 393. 1812; Pedilanthus tithymaloides (L.) Poit. ssp. angustifolius (Poit.) Dressler, Contr. Gray Herb. 182: 161. 1957).

Euphorbia tithymaloides L. ssp. bahamensis (Millsp.) V. W. Steinm., comb. nov. (=Pedilanthus tithymaloides (L.) Poit. ssp. bahamensis Dressler, Contr. Gray Herb. 182: 165. 1957).

Euphorbia tithymaloides L. ssp. jamaicensis (Millsp. \& Britton) V. W. Steinm., comb. nov. (=Pedilanthus jamaicensis Millsp. \& Britton, Publ. Field Mus. Natl. Hist., Bot. ser. 2: 356. 1913; Pedilanthus tithymaloides (L.) Poit. ssp. jamaicensis (Millsp. \& Britton) Dressler, Contr. Gray Herb. 182: 165. 1957).

Euphorbia tithymaloides L. ssp. padifolia (L.) V. W. Steinm., comb. nov. (=Euphorbia tithymaloides L. var. padifolia L., Sp. PI. 453. 1753; Pedilanthus tithymaloides (L.) Poit. ssp. padifolius (L.) Dressler, Contr. Gray Herb. 182: 156. 1957). 
Euphorbia tithymaloides L. ssp. parasitica (Klotzsch \& Garcke) V. W. Steinm., comb. nov. (=Pedilanthus parasiticus Klotzsch \& Garcke, Abh. Königl. Akad. Wiss. Berlin 1859 (Phys. Abh.): 159. 1860; Pedilanthus tithymaloides (L.) Poit. ssp. parasiticus (Klotzsch \& Garcke) Dressler, Contr. Gray Herb. 182: 148. 1957).

Euphorbia tithymaloides L. ssp. retusa (Benth.) V. W. Steinm. comb. nov. (=Pedilanthus retusus Benth., Hooker's J. Bot. Kew Gard. Misc. 6: 321. 1854; Pedilanthus tithymaloides (L.) Poit. ssp. retusus (Benth.) Dressler, Contr. Gray Herb. 182: 154. 1957).

Euphorbia tithymaloides L. ssp. smallii (Millsp.) V. W. Steinm. comb. nov. (=Pedilanthus smalliii Millsp., Publ. Field Mus. Natl. Hist., Bot. ser. 2: 358. 1913; Pedilanthus tithymaloides (L.) Poit. ssp. smallii (Millsp.) Dressler, Contr. Gray Herb. 182: 152. 1957).

\section{ACKNOWLEDGEMENTS}

I thank Robert L. Dressler and two anonymous reviewers for providing critical comments and corrections of the manuscript.

\section{LITERATURE CITED}

Carter, S. 1988. Euphorbieae. In: Polhill, R. M. (ed.). Flora of Tropical East Africa, Euphorbiaceae. A. A. Balkema, Rotterdam. pp. 409-564.

Dressler, R. L. 1957. The genus Pedilanthus (Euphorbiaceae). Contrib. Gray Herb. Harvard Univ. 182: 1-188.

Johnston, M. C. 1975. Studies of the Euphorbia species of the Chihuahuan desert region and adjacent areas. Wrightia 5: 120-143.

Klotzsch, J. F. and C. A. F. Garcke. 1859 (1860). Hr. Klotzsch las über Linné's natürliche Pflanzenklasse Tricoccae des Berliner Herbarium's im Allgemeinen und die natürliche Ordnung Euphorbiaceae insbesondere. Monatsber. Königl. Preuss. Akad. Wiss. Berlin 1859: 236-254.

Klotzsch, J. F. and C. A. F. Garcke. 1860. Linné's natürliche Pflanzenklasse Tricoccae. Abhandl. Königl. Preuss. Akad. Wiss. Berlin 1859 (Phys. Abhandl.): 1-108.

Linnaeus, C. 1753. Species Plantarum. Impensis Laurentii Salvii, Stockholm. 1200+31 pp.

Steinmann, V. W. and J. M. Porter. 2002. Phylogenetic relationships in Euphorbieae (Euphorbiaceae) based on ITS and ndhF sequence data. Ann. Missouri Bot. Gard. 89: 453-490.

Webster, G. L. 1967. The genera of Euphorbiaceae in the southeastern United States. J. Arnold Arb. 48: 303-361, 363-430.

Webster, G. L. 1994. Synopsis of the genera and suprageneric taxa of Euphorbiaceae. Ann. Missouri Bot. Gard. 81: 33-144. 